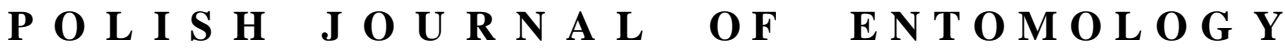

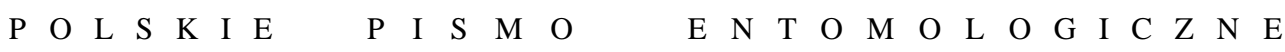

VOL. 85: 135-146

Lublin

30 March 2016

DOI: $10.1515 /$ pjen-2016-0007

\section{The first record of the yew gall midge Taxomyia taxi (INCHBALD, 1861) (Diptera: Cecidomyiidae) in the Polish Carpathians, southern Poland}

\author{
JAN BODZIARCZYK ${ }^{*}$, MARCIN WIDLAK, MALWINA SIWY \\ Department of Forest Biodiversity, Institute of Forest Ecology and Silviculture, Faculty \\ of Forestry, University of Agriculture, Al. 29 November 46, 31-425 Kraków, Poland
}

\begin{abstract}
The yew gall midge Taxomyia taxi has been found for the first time in the Polish Carpathians. The site lies in the "Yews in Mogilno" ("Cisy w Mogilnie") nature reserve in the western part of the Beskid Niski (Low Beskid) Mountains. The species occurs over an area of ca. 37 ha, mostly in the northern, lowest-lying parts of the reserve. $19.4 \%$ of the inspected specimens of the European yew were found to exhibit signs of feeding by gall midges. Most of the infested yews $(86.7 \%)$ were barren, $8.2 \%$ were females and $5.1 \%$ males. The yew gall midges displayed no clear preferences in relation to the health status of the host plants, although yews with a healthier photosynthetic apparatus were selected more often.
\end{abstract}

KEY WORDS: Diptera, Cecidomyiidae, relict species, Taxomyia taxi, Taxus baccata, gall midge, pest, Beskid Niski Mountains, Poland.

\section{INTRODUCTION}

The yew gall midge Taxomyia taxi (INCHBALD, 1861) (Diptera: Cecidomyiidae) is a rare monophagous species closely associated with the European yew Taxus baccata LINNAEUS, 1753 (BuHr 1965, SKuHRAVÁ 1965, LOVETT \& CHAPPELl 1970, REDFERN 1975, POSTNER 1982, JANEČEK \& EŠNEROVÁ 2012). It causes the development of galls resembling rosettes up to $20 \mathrm{~mm}$ long, with shortened and discoloured needles. Each cecidium contains a chamber with an orange gall midge larva. The life cycle of the yew gall midge lasts two years, rarely longer, but a small percentage of the population $(<10 \%)$ may go through

\footnotetext{
* Corresponding author: rlbodzia@cyf-kr.edu.pl
} 
a one-year cycle (REDFERN 1975). Depending on the weather conditions, swarming occurs from late April to mid-May (SKUHRAVÁ 1964, SKUHRAVÝ \& SKUHRAVÁ 1998). The female lays single eggs (rarely up to 10) on the yew buds or on the underside of the needles (REDFERN 1975). Larval development takes place over two seasons, and pupation occurs in spring (BUHR 1964-1965, SIWECKI 1975, SKUHRAVÝ \& SKUHRAVÁ 1998). The adult is up to 3-4 mm long (SZADZIEWSKI 1999); the colour of the head and pronotum is brown-orange, and the abdomen is yellowish with darker stripes.

Despite the broad distribution of the gall midge and its host, the European ranges of both species overlap (SKUHRAVÁ et al. 2008). In Poland, T. taxi has been reported from only a few lowland nature reserves (RÜBSAAMEN 1901, SZADZIEWSKI 1976, ŁABĘDZKI 1995). The abundant occurrence of this gall midge was described only from the Leon Wyczółkowski Cisy Staropolskie Nature Reserve in Wierzchlas (SIWECKI 1975).

This information relating to T. taxi in the "Yews in Mogilno" nature reserve is the first observation of this species in the Polish Carpathians (Fig. 1), and this finding has prompted further research on $T$. taxi. Undertaking the research was justified, all the more so because negative processes have been observed in this yew population for several years, manifested by a decline in the condition of individual trees, reduced seed yields and regeneration, which in consequence may lead to population development ceasing altogether (BODZIARCZYK et al. 2015). Such research is taking on particular importance as this is one of the largest yew populations in the western Carpathians.

The main purpose of the study was to assess the increasing occurrence of $T$. taxi and its impact on the health of the European yew population in this nature reserve.

\section{Acknowledgements}

We are grateful to Professor Małgorzata SKRZYPCZYŃSKA for reading the text and her valuable comments, which helped us to draw up the final version of the paper. We thank the anonymous reviewers for their helpful comments on the manuscript.

The study was supported by the Polish Ministry of Science and Higher Education grant no. DS 3421/ZBL/2015.

\section{MATERIAL AND METHODS}

The "Yews in Mogilno" ("Cisy w Mogilnie") nature reserve (area 35.67 ha), established in 1963, is situated in the south-east of the province of Małopolska $\left[49^{\circ} 38^{\prime} 18^{\prime \prime} \mathrm{N}\right.$; $\left.20^{\circ} 49^{\prime} 45^{\prime \prime} \mathrm{E}\right]$. It lies mostly on northerly slopes of greatly varying inclination (from $5^{\circ}$ to $50^{\circ}$ ), while the altitude varies between 550 and $714 \mathrm{~m}$ amsl. There are as many as 1272 European yew trees taller than $0.5 \mathrm{~m}$ in the reserve; none is more than 120 years old. 


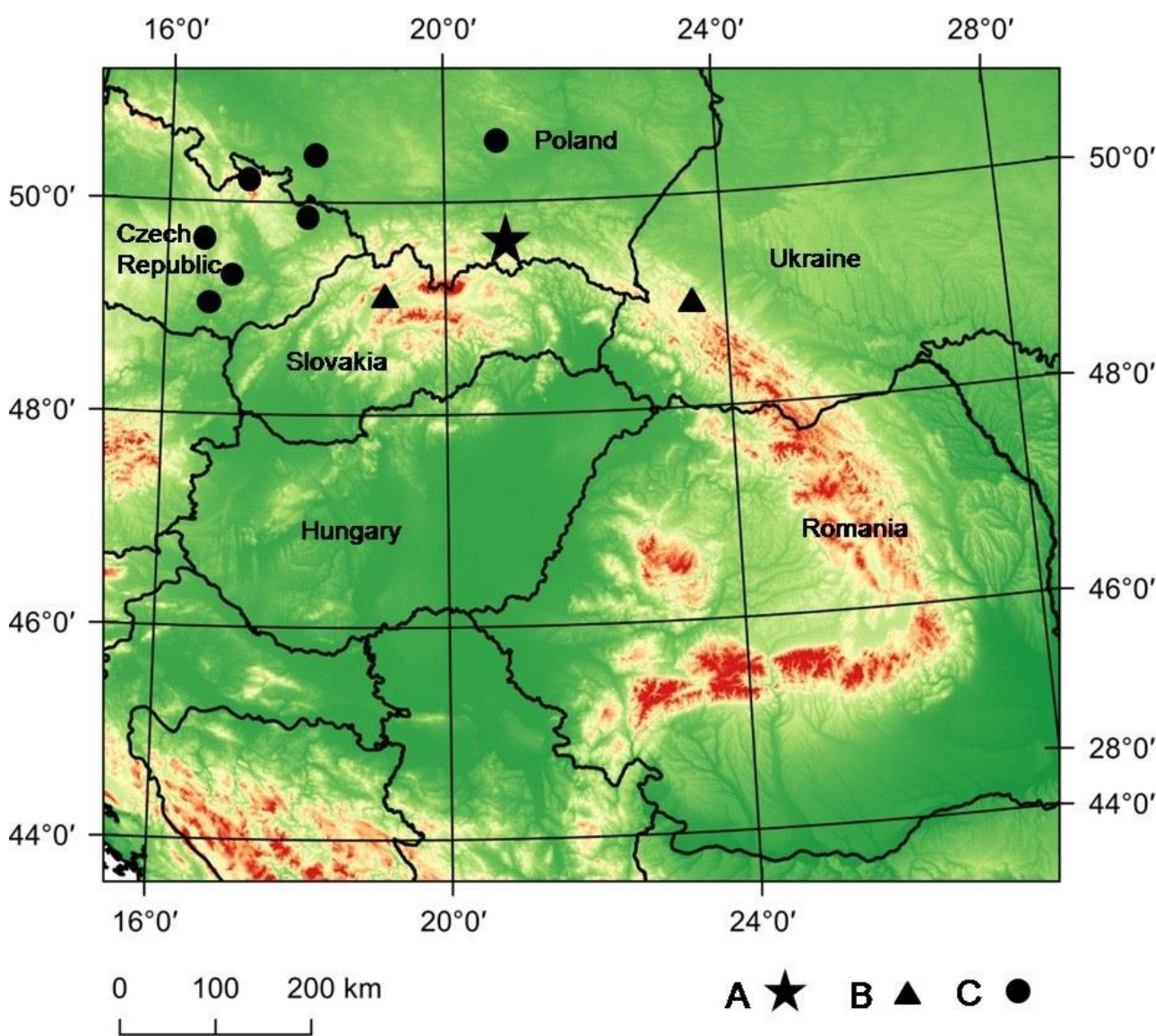

Fig. 1. Location of the newly discovered site of Taxomyia taxi in relation to the Carpathians. A - the newly discovered site; $\mathrm{B}$ - the sites known from the literature; $\mathrm{C}-$ the nearest sites beyond the Carpathians (http://gis-lab.info/qa/vmap0-eng.html).

The research was conducted in 2011 and 2012 on 1209 specimens of the European yew Taxus baccata scattered over an area of ca. 37 ha. The crown of each yew was thoroughly checked for signs of the presence of Taxomyia taxi. The height and diameter at breast height (DBH) of the yews were measured, the sex was determined and the health status of the tree crown assessed according to criteria accepted a priori (BODZIARCZYK \& ZATOR 2004). In addition, yew shoots with symptoms of gall-midge infestation were collected in May 2014 for laboratory culture.

The coordinates of each individual tree were determined using a GPS receiver (GPSmap $60 \mathrm{CSx}$ ) in order to prepare a detailed map showing the distribution of all the yews. In addition, the altitude, exposure and slope of their occurrence were described. The relative 
direct solar radiation was calculated using the tables by STRUŽKA (1954). The MannWhitney U-test was applied to compare the distributions of tree BHD and height. Basic statistical characteristics were also calculated.

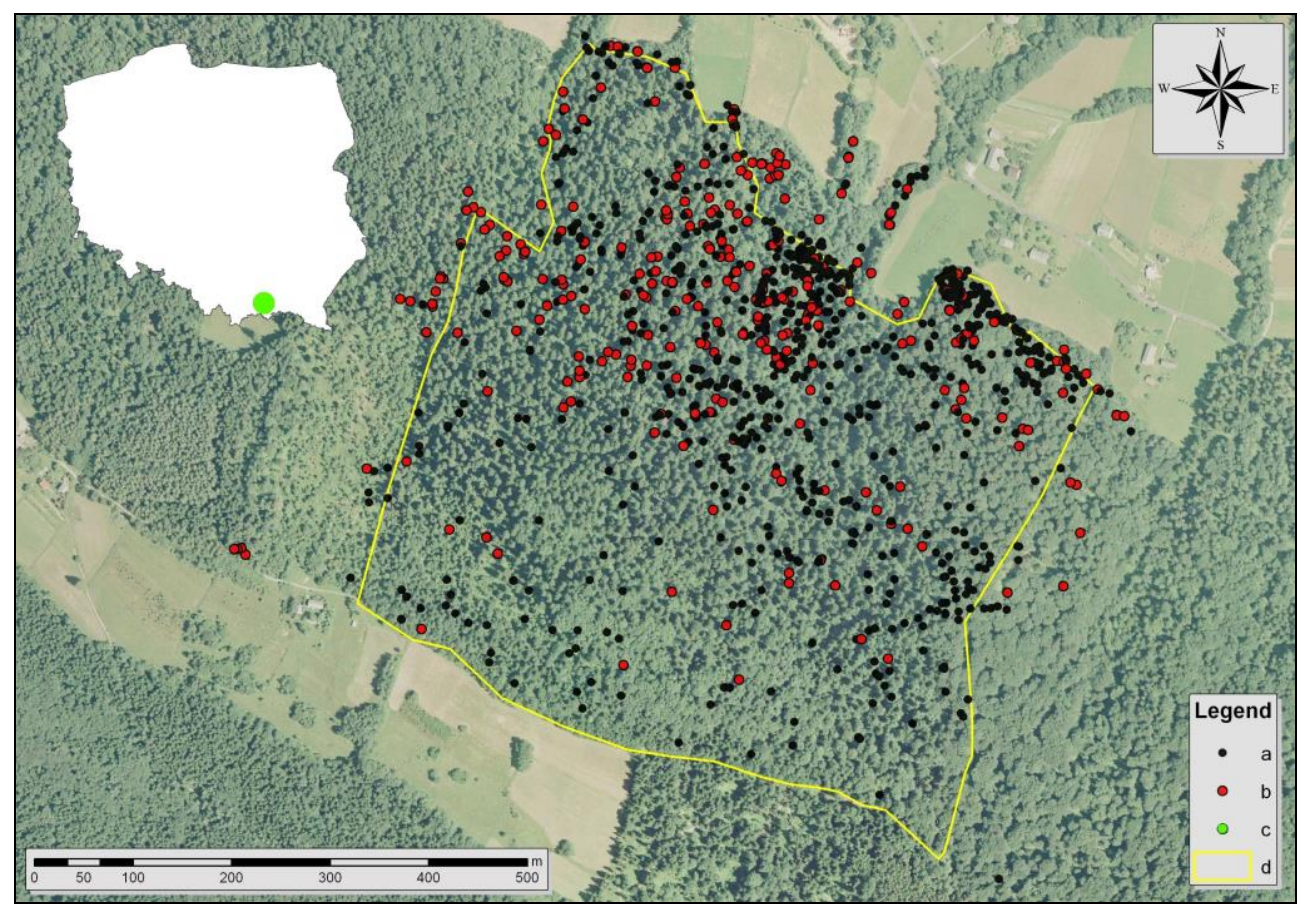

Fig. 2. Distribution of the European yew Taxus baccata in the "Yews in Mogilno" nature reserve [www.geoportal.gov.pl]. Explanations: a - trees without Taxomyia taxi; b - trees with T. taxi; c - location of the nature reserve "Yews in Mogilno"; $\mathrm{d}$ - boundaries of the nature reserve.

\section{RESULTS}

The presence of Taxomyia taxi galls was observed on yews growing over the entire nature reserve and in the immediate vicinity of its borders (Fig. 2). Galls were found in $19.4 \%$ of trees in the yew population (Fig. 3). Most of the infested yews were barren - they were predominant in this population. Among the mature yews, $8.2 \%$ of female trees and $5.1 \%$ of males were infested by $T$. taxi. Yews with galls were mostly represented by trees $(80.3 \%)$; only rarely were the yews in the form of shrubs. Gall midges occurred mainly in the northern and north-western parts of the nature reserve $(570-620 \mathrm{~m} \mathrm{amsl})$, where the 
highest density of yews is found. Specific microhabitat conditions prevail in the lowestlying parts of the nature reserve. These are cooler and more humid sites, mainly steep slopes with a northerly exposure, where the relative direct solar radiation for the vast majority of yews does not exceed $100 \%$ (Fig. 4). Yews infested by galls of T. taxi were usually growing in places where the canopy cover of the trees over the yews ranged from 60 to $100 \%$. Only a few infested yews were found under a tree canopy of ca. $20 \%$.

As evidenced by the measurements of trunk thickness and height, $T$. taxi displayed no clear preferences for any particular size of these trees (Fig. 5). The largest yew showing signs of gall-midge infestation had a DBH of $30.9 \mathrm{~cm}$ and a height of $11.5 \mathrm{~m}$; the corresponding figures for the smallest one were up to $1.3 \mathrm{~cm}$ and $1.5 \mathrm{~m}$, respectively. It follows from the biometric measurements that yews injured by $T$. taxi have a smaller-thanaverage DBH $\left(\mathrm{x}_{\mathrm{dbh}}=13.8 \mathrm{~cm}\right)$ compared to non-infested specimens $\left(\mathrm{x}_{\mathrm{dbh}}=14.2 \mathrm{~cm}\right)$. Comparison of the distribution of DBHs and the height of yews infested by galls with their distribution for non-infested yews did not yield any statistically significant differences (for DBH: $\mathrm{z}=0.417693, p=0.67612$; for the height: $\mathrm{z}=-1.2860, p=0.19681$ ).

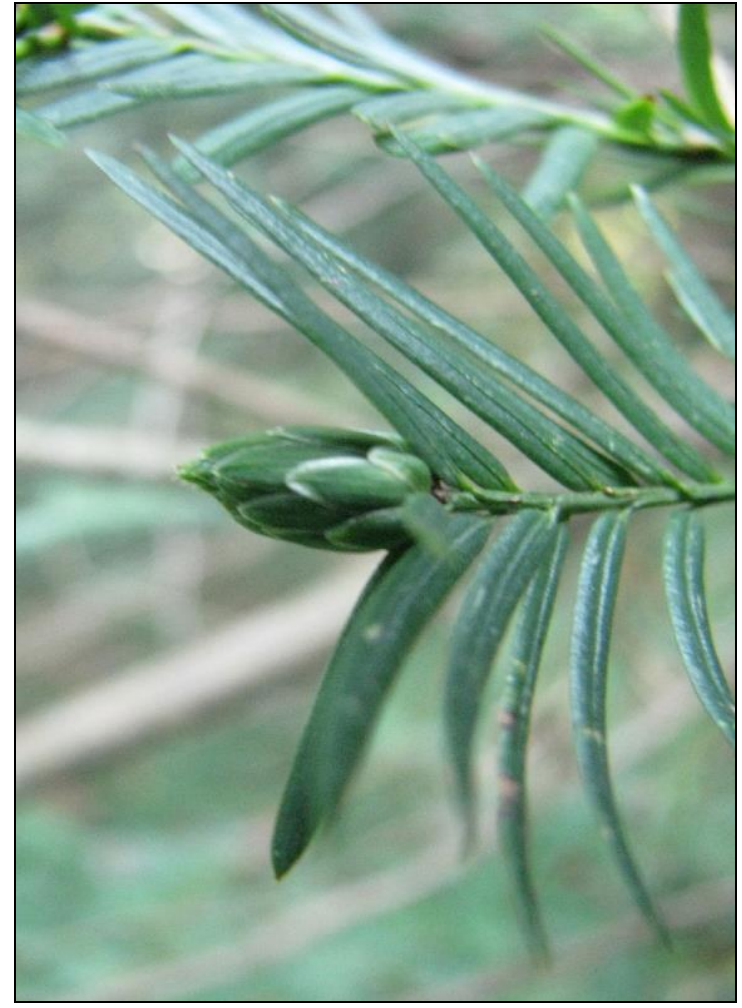

Fig. 3. Rosette gall on the shoot of an European yew - the response to the feeding of Taxomyia taxi larvae inside the bud (17.09.2014). (Photo by J. BODZIARCZYK). 


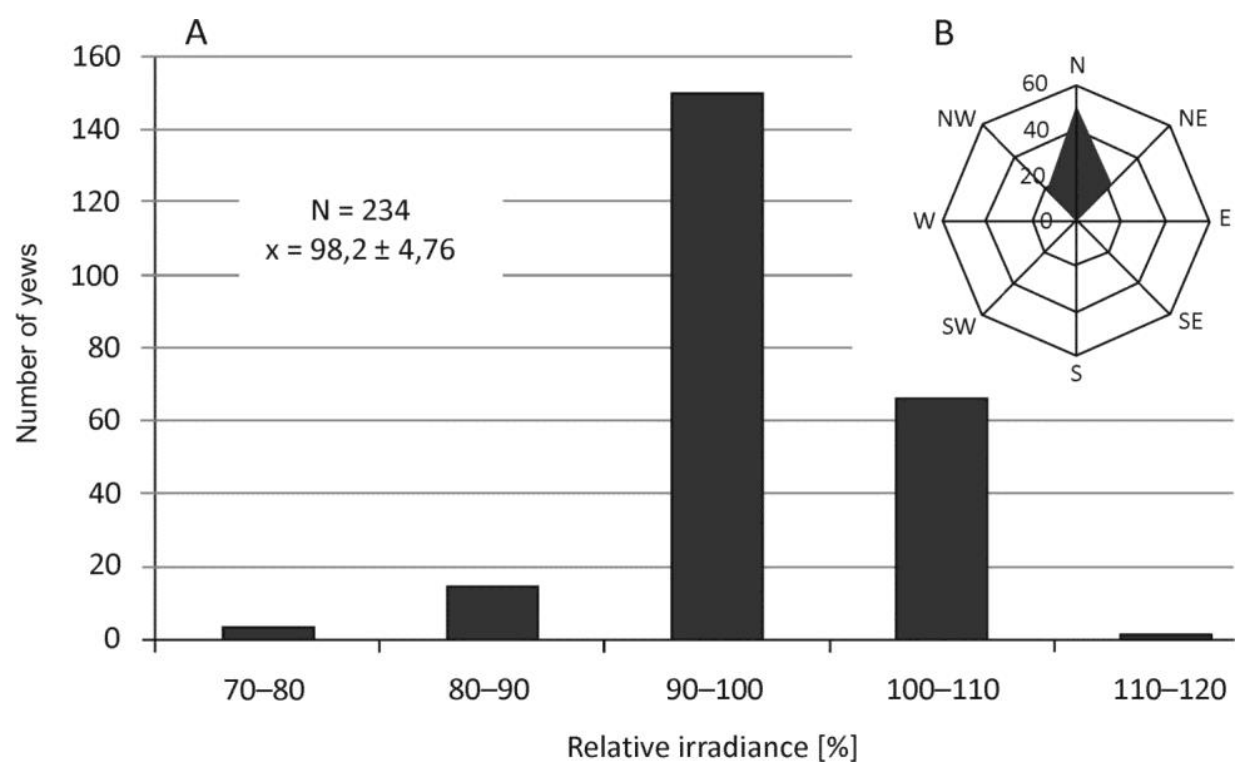

Fig. 4. Effect of solar radiation (A) and exposure (B) on the occurrence of Taxomyia taxi in the "Yews in Mogilno" nature reserve.

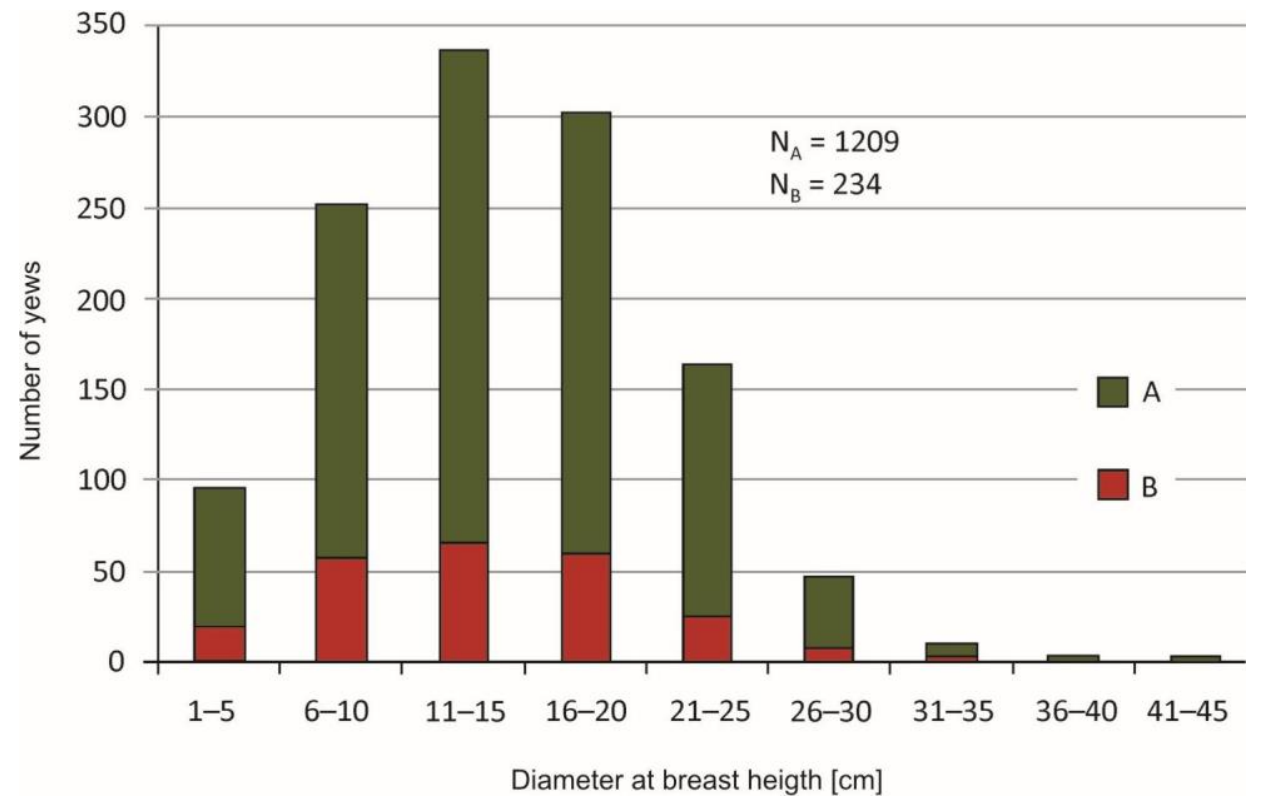

Fig. 5. Relations between the occurrence of Taxus baccata without Taxomyia taxi galls (A) and with Taxomyia taxi galls (B) and host tree age, expressed by the thickness of trunks measured as diameter at breast height in the "Yews in Mogilno" nature reserve. 
Analysis of the health status of yew tree crowns infested by $T$. taxi indicates that the yew gall midge more often selected trees with healthy and viable crowns than trees in poorer condition. In total, $59 \%$ of yews were viable, very healthy individuals, with livegreen crowns without any visible symptoms of disease, $7 \%$ were specimens with obvious symptoms of deteriorating health and $1 \%$ were moribund (Fig. 6).

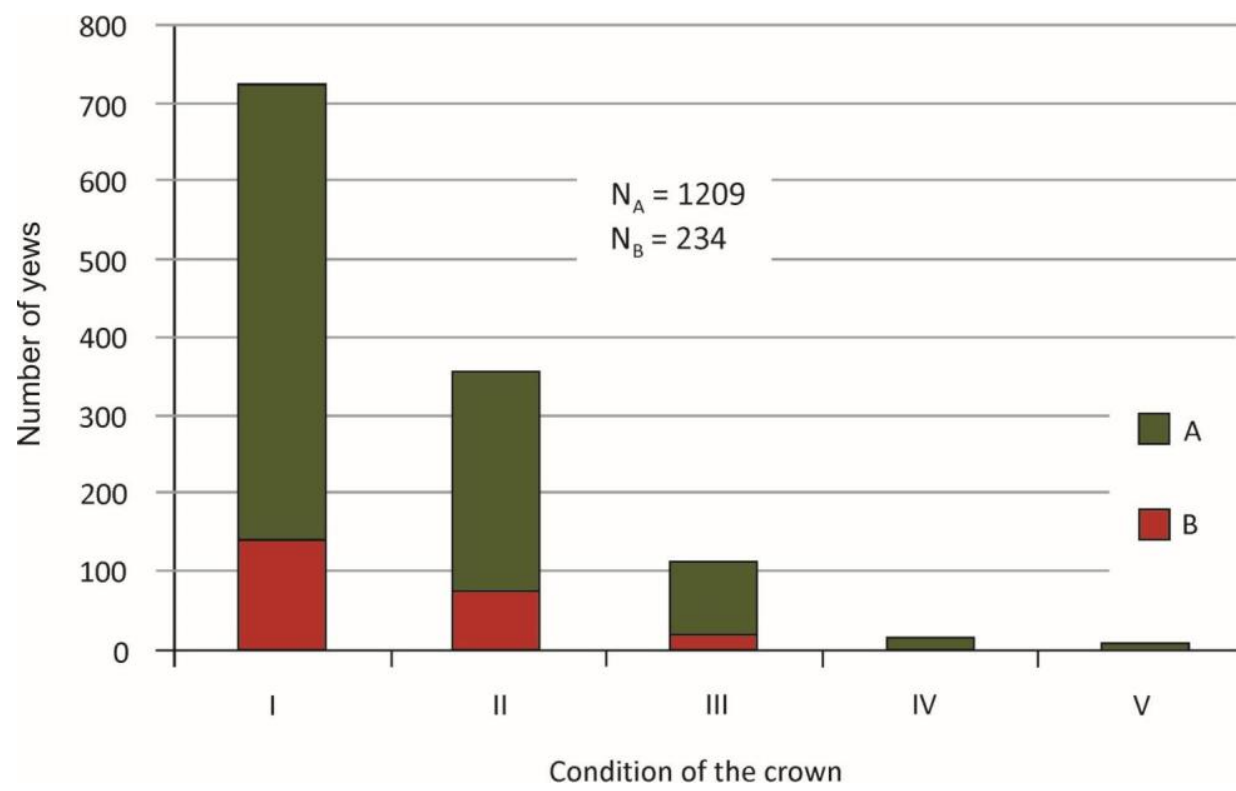

Fig. 6. Relationship between the occurrence of Taxomyia taxi and the state of health of Taxus baccata crowns in the "Yews in Mogilno" nature reserve. Explanation: A - all yew trees in the nature reserve; B - trees with galls of Taxomyia taxi; I - healthy yew crowns, bright green, without signs of defoliation; II - healthy yew crowns, bright green, $<10 \%$ of the photosynthetic apparatus damaged or discoloured in the whole crown; III - weakened crown with visible discolouration of the photosynthetic apparatus; IV - moribund crown, $>50 \%$ of needles damaged or discoloured; $\mathrm{V}$ - dead specimens.

A total of 6 imagines were reared in laboratory conditions from the collected material (26 May 2014) in the form of dozens of yew shoots from the "Yews in Mogilno" nature reserve. Hatching took place immediately after the culture was established (from 26 to 29 May 2014). In the course of the observations, it was found that some yew shoots with galls were abandoned by T. taxi imagines (Fig. 7) prior to the sampling of shoot samples, which may have had something to do with the early spring. 


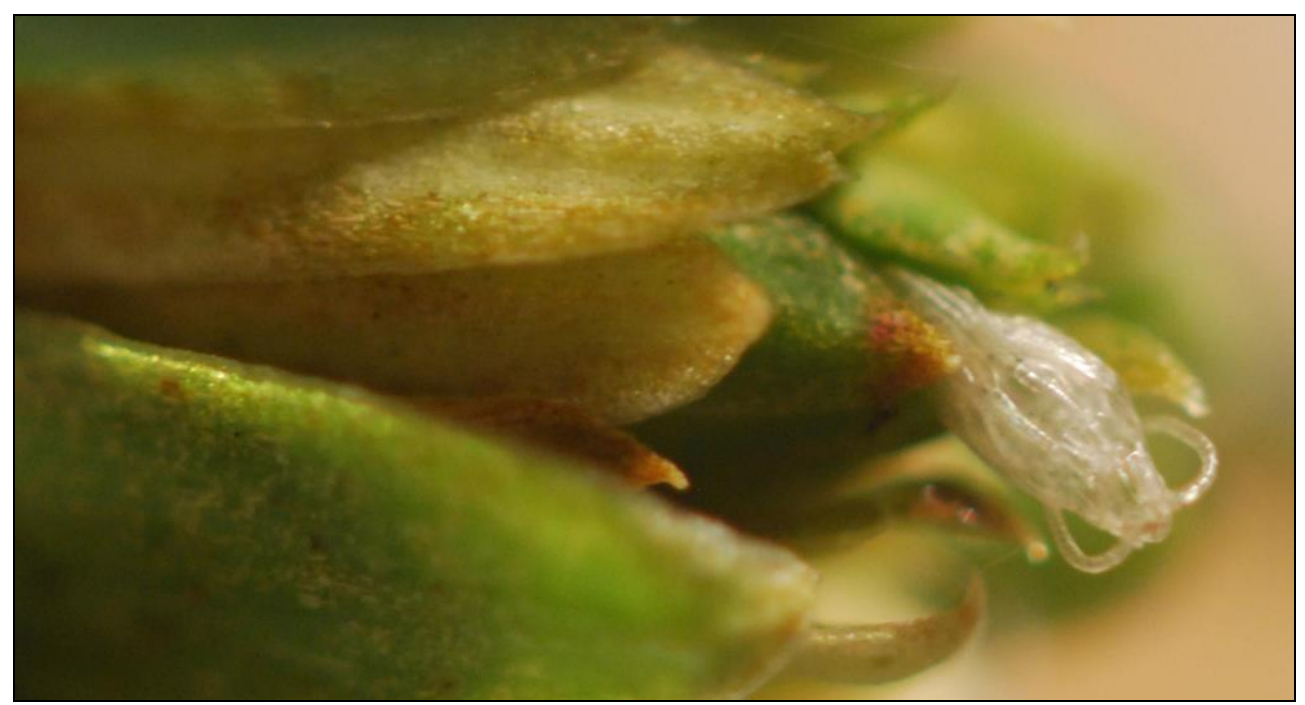

Fig. 7. Pupal exuviae of Taxomyia taxi immediately after leaving a gall on a European yew Taxus baccata (May 2014) (Photo by M. WIDLAK).

\section{DISCUSSION}

The only data on the occurrence of Taxomyia taxi galls in the eastern Carpathians come from nearly 80 years ago and they refer to observations from the Bieszczady Mountains (Fig. 1), where they were observed on two yews in the then Forest Division of Majdan (now Ukrainian territory) (KozIKOWSKI 1937). Galls of T. taxi on Taxus baccata were found at Harmanec in the western Carpathians (central Slovakia) by PAŠEK (1951) - this area is now in the Harmenecká tisina nature reserve in the Velká Fatra National Park.

In Poland, the hitherto known sites of $T$. taxi in the "Radomice" nature reserve and in the "Yews in Huta Stara" nature reserve are $120 \mathrm{~km}$ to the north and ca. $200 \mathrm{~km}$ to the north-west, respectively, of the newly discovered site in Mogilno (LABĘDZKI 1995). Another site, within a similar distance $(185 \mathrm{~km})$, lies in the north-eastern part of the Czech Republic (SKUHRAVÝ \& SKUHRAVÁ 1998).

Little is known about the ecology of this species. Most of the available information refers to the range of occurrence (e.g. UNAL \& AKKUZU 2009, KOLLÁR 2011), and only a few works relate to the species' biology (SKUHRAVÁ 1964, LOVETT 1980, RAMAN 1984, REDFERN \& CAMERON 1993). Long-term research on the dynamics of T. taxi and attempts to link these dynamics with the development of its parasitoids and climatic factors are of particular importance (REDFERN \& HUNTER 2005). 
According to BUHR (1964-65, as cited in SzUJECKI 1998), T. taxi selects only male flower buds. The current research shows, however, that $T$. taxi selects yews regardless of their sex. Our results endorse the results of research from other regions, e.g. Slovakia where PAŚEK (1951) found damaged yew buds on specimens of both sexes. In Mogilno, barren yews of indeterminate sex represented the predominant fraction of infested trees. Galls were not found on yews at younger developmental stages, the height of which did not exceed $1.5 \mathrm{~m}$.

The yew gall midge T. taxi is usually regarded as a forest pest (SIWECKI 1975, SCHNAIDER 1976). According to SKUHRAVÁ \& ROQUES (2000) this species lowers the growth rate of yews. In Poland, given the small number of records of the yew gall midge (SKUHRAVÁ \& SKRZYPCZYŃSKA 1983, ŁABĘDZKI 1995, SKUHRAVÁ et al. 2008), the impact of this pest on the native populations of this protected tree species is likely to be negligible. To local yew populations, however, the yew gall midge may represent a threat, especially when it occurs abundantly. This is confirmed by the observations from the "Wierzchlas" nature reserve, where at first no threat was perceived (PRÜFFER 1950). Over the next 20 years, however, the yew gall midge began to significantly reduce yew growth: this was first reported by SZCZEPAŃSKI (1973) and later confirmed by other researchers. By 1991-1993, $53.5 \%$ of yew trees in the "Wierzchlas" reserve were infested by T. taxi (ŁABĘDZKI 1995), and their annual growth increment was 20-25\% less than that of reference trees.

Our two-year observations in the "Yews in Mogilno" nature reserve that the number of yew trees infested by the yew gall midge has gradually increased. At the same time, the flowering and seed yield of the yews have deteriorated over the past 5-10 years. At present, only $14 \%$ of the yew trees in the population develop flowers and produce seeds, a figure three times lower than 10 years ago. It should also be mentioned that this is the only Carpathian population of yews with such unfavourable percentages of mature and barren specimens, i.e. $14 \%$ and $86 \%$, respectively. As no direct evidence is available on the impact of the yew gall midge on yew flowering and maturation, further research should address this issue. The growing population size of this gall midge, reflected in the large-scale colonization of yew shoots, is likely to have an impact on annual growth increments in the host plant.

Despite the many detailed population studies of yews by e.g. BODZIARCZYK \& ZATOR (2004), BoDZIARCZYK \& RUŻYŁO (2007), BODZIARCZYK \& CHACHUŁA (2008), BODZIARCZYK \& RAMUT (2011) in the Polish Carpathians, T. taxi has not yet been found beyond Mogilno. So far it is unclear what factors affect the limited geographical distribution of the yew gall midge. The Mogilno reserve is a montane site, but it lies closer to the Carpathian Foothills than any other known montane population of yews in Poland. The large dispersal of yew sites and the limited potential for T. taxi movements are also of 
major significance. It seems likely that these factors are playing a key role and are determining the species' current distribution range.

According to BERTONE et al. (2008), the yew gall midge represents an old phylogenetic group of relict organisms, like the European yew itself, which is the oldest tree species in Europe (HAGENDER 2007). The fact that Taxomyia taxi has been observed at this yew locality is thus an important argument in favour of its natural origin.

\section{REFERENCES}

Bertone M.A., Courtney G.W., Wiegmann B.M. 2008. Phylogenetics and temporal diversification of the earliest true flies (Insecta: Diptera) based on multiple nuclear genes. Systematic Entomology 33(4): 668-687.

BODZIARCZYK J., ZATOR A. 2004. Distribution, structure and habitat conditions of the population of European yew Taxus baccata L. in the Łysa Góra massif of the Beskid Niski range. Acta Agraria et Silvestria series Silvestris 42: 3-22. (in Polish)

BODZIARCZYK J., RuŻYŁo T. 2007. Conditions of occurrence, structure, and health status of the population of common yew Taxus baccata L. in the "Cisy na Górze Jawor" nature reserve, Bieszczady Mts, Poland. Roczniki Bieszczadzkie 15: 163-179. (in Polish)

BodziarczYK J., ChachuŁa P. 2008. Population structure of common yew Taxus baccata L. in the "Cisy w Serednicy" [Yews at Serednica] nature reserve in the Góry Słonne Mountains (Western Bieszczady Mts.), Poland. Roczniki Bieszczadzkie 16: 191-214. (in Polish)

BoDZIARCZYK J., RAMUT M. 2011. Structure and health status of the common yew population in the production forests, Bieszczady Mts, Poland. Roczniki Bieszczadzkie 19: 77-95. (in Polish)

BodZiarczyK J., Siwy M., WidlaK M. 2015. Structure, dynamics and health of the common yew Taxus baccata L. in the "Cisy w Mogilnie" nature reserve (Western Carpatians). Chrońmy Przyrodę Ojczystą 71(6): 403-421. (in Polish)

BuHR H. 1964-1965. Bestimmungstabellen der Gallen (Zoo- und Phytocecidien) an Pflanzen Mittelund Nordeuropas. Gustav Fischer Verlag, Jena.

Hagender F. 2007. Yew. A History. Sutton Publishing, Stroud, Gloucestershire.

JANEČEK V., EŠNEROVÁ J. 2012. European yew - Taxus baccata. Lesnická Práce 91(3/12): 40-41. (in Czech)

Kollár J. 2011. Gall-inducing arthropods on ornamental plants in Nitra (SW Slovakia). Acta entomologica serbica 16(1/2): 115-126.

KozIKOwSKi K. 1937. European yew in the forest inspectorates Majdan and Pobuż in Bieszczady Mts. Sylwan (A) 55: 141-151. (in Polish)

LOVETT T. J. 1980. Some phytochemical changes in Taxus baccata L. shoots associated with stages in the life cycles of Taxomyia taxi (INCH.). Bulletin de la Société botanique de France 127(1): 129-136. 
Lovett T. J., Chappell H. G. 1970. A note on the life cycle of the gall midge Taxomyia taxi (INCH.) on Taxus baccata L. Marcellia 36: 257-260.

ŁABĘDZKI A. 1995. Entomofauna inhabitins the European yew Taxus baccata L. in selected reserves in Poland. Parki Narodowe i Rezerwaty Przyrody 13(1)(Suppl.): 83-90. (in Polish)

PAŠEK V. 1951. The Needle-Shortening Gall Midge (Thecodiplosis brachyntera SCHWÄGR.) and two other intesting Thecodiplosis species from Slovakia. Lesnická Práce 30(2): 146-149. (in Czech)

Postner M. 1982. Cecidomyidae (=Itonididae), Gallmücken. [in:] W. SChwENKE (ed.). Die Forstschädlinge Europas. Hautflügler und Zweiflügler. Band IV. Verlag Paul Parey, Hamburg Berlin, 291-317.

PRÜFFER J. 1950. Some peculiarities in the entomofauna of the yew preserve Wierzchlas. Studia Societatis Scientiarum Torunensis E II(6): 146-176. (in Polish)

RAman A. 1984. Gall insect-host plant relationships-An ecological perspective. Proceedings of the Indian Academy of Sciences (Animal Sciences) 93(4): 293-300.

REDFERN M. 1975. The life history and morphology of the early stages of the yew gall midge Taxomyia taxi (INCHBALD) (Diptera: Cecidomyiidae). Journal Natural History 9(5): 513-533.

Redfern, M., CAMERon R.A.D. 1993. Population dynamics of the yew gall midge Taxomyia taxi and its chalcid parasitoids: a 24-year study. Ecological Entomology 18(4): 365-378.

RedFern M. , Hunter M.D. 2005. Time tells: long-term patterns in the population dynamics of the yew gall midge, Taxomyia taxi (Cecidomyiidae), over 35 years. Ecological Entomology 30(1): $86-95$.

RÜBSAAMEN E. H. 1901. Bericht über meine Reise durch die Tucheler Heide in den Jahren 1896 und 1897. Schriften der Naturforschenden Gesellschaft in Danzig 10: 1-70.

SCHNAIDER Z. 1976. Atlas of trees and shrubs damages caused by insects and spiders. PWN, Warszawa. (in Polish)

SIWECKI R. 1975. Diseases and parasitic insects of the European yew (Taxus baccata). [in:] S. BiAŁoboK (ed.). Our forest trees. III. The European yew. PWN, Warszawa - Poznań, 123-133. (in Polish)

SKuHRAVÁ M. 1964. Zur Morphologie und Bionomie der Eibengallmücke Taxomyia taxi (INCHBALD) (Diptera, Itonididae). Časopis Československé Společnosti Entomologické 61: 106-112.

Skuhravá M. 1965. Distribution of the Yew Gall Midge Taxomyia taxi (InchBald) and its noxiousness in the Czechoslovak Socialist Republic. Lesnický časopis 11(1): 71-78. (in Czech)

Skuhravá M., Roques A. 2000: Palaearctic dipteran forest pests. [in:] L. PAPP, B. Darvas (eds.). Contributions to a Manual of Palaearctic Diptera. Vol. 1. General and Applied Dipterology. Science Herald, Budapest, 651-692.

SkUhravÁ M., SkrzypCZYŃSKa M. 1983. A review of gall-midges (Cecidomyiidae, Diptera) of Poland. Acta Zoologica Cracoviensia 26(12): 38-420. (in Polish)

SkuhravÁ M., SkuhravÝ V., SkrZypczyŃSKa M., SZADZIEWSKi R. 2008. Gall midges (Cecidomyiidae, Diptera) of Poland. Pryszczarki (Cecidomyiidae, Diptera) Polski. Annals of the Upper Silesian Museum (Entomology) 16: 5-160.

SkuhravÝ V., Skuhravá M. 1998. Gall Midges of Forest Trees and Shrubs. Matice lesnická, Písek. 
STRUŽKa V. 1954. Methods of climatic studies. [in:] J. KLIKA, V. NovÁK, A. GREGOR (eds.). Manual of. Phytocenology, Ecology, Climatology and Pedology. Czechoslovak Academy of Sciences, Prague, 259-267. (in Czech)

SZADZIEWSKi R. 1976. Notes on gall midges (Cecidomyiidae, Diptera) from Poland. I. Bulletin Entomologique de Pologne 46(4): 729-743.

SZADZIEWSKI R. 1999. Recognition of gall midges (Diptera: Cecidomyiidae). [in:] J. BocZEK (ed.). Diagnosis of plant pests and their natural enemies. Volume III. Wydawnictwo SGGW, Warszawa, 137-241. (in Polish)

SzCZEPAŃSKI H. 1973. The health of the yew trees, Taxus baccata, in the nature reserve of Wierzchlas. Chrońmy Przyrodę Ojczystą 29(2): 60-63. (in Polish)

SzUJECKI A. 1998. Forest Entomology, Vol. I. Wydawnictwo SGGW, Warszawa. (in Polish)

UnAl S., AKKuZu E. 2009. Forest Gall Midge Fauna (Diptera: Cecidomyiidae) of Turkey. Research Journal of Agriculture and Biological Sciences 5(9): 915-922.

Received: 23 June 2015

Accepted: 18 November 2015 